\title{
RISK FACTORS OF ACTIVE TUBERCULOSIS IN PEOPLE LIVING WITH HIV/AIDS IN SOUTHWEST ETHIOPIA: A CASE CONTROL STUDY
}

\author{
Mohammed Taha ${ }^{1}$, Amare Deribew ${ }^{1,2^{*}}$, Fasil Tessema ${ }^{1}$, Sahilu Assegid ${ }^{1}$, Luc \\ Duchateau $^{3}$, Robert Colebunders ${ }^{2,4}$
}

\section{ABSTRACT}

BACKGROUND: Determinants of active tuberculosis among People Living with HIV/AIDS (PLHA) are not well elucidated in countries with limited resources. The objective of this study was to assess distal and proximate determinants of active tuberculosis among people living with HIV/AIDS in southwest Ethiopia.

METHODS: A case-control study was conducted from January to March, 2009 in South West Ethiopia. The study population consisted of 162 cases and 647 controls. Cases were adult people living with HIV/AIDS who developed active pulmonary tuberculosis and controls were people living with HIV/AIDS without active tuberculosis. An interviewer administered structured questionnaire was used to collect information on potential risk factors.

RESULTS: After adjustment for potential confounders, male gender (OR=1.7; 95\%CI: 1.1, 2.7), a low level of education (OR=2.8; 95\% CI: 1.1, 7.1), a body mass index less than $18.5 \mathrm{~kg} / \mathrm{m} 2$ (OR=4.1; 95\% CI: 2.3, 7.4), hemoglobin level less than $10.0 \mathrm{~g} / \mathrm{dl}$ (OR=2.8; 95\%CI: 1.5, 5.2), a CD4 lymphocyte count less than 200 cells/ $\mu \mathrm{L}$ (OR=9.8‘95\% CI: 5.5, 17.5), a WHO clinical stage IV (OR=4.3; 95\% CI: 2.6, 6.8), not taking antiretroviral treatment $(O R=3.1 ; 95 \% C I$ : 1.9,4.9), an infection with helminthes $(O R=2.2 ; 95 \%$ CI: 1.4, 3.4), a history of contact with a tuberculosis patient in the family (OR=2.0; 95\% CI: 1.2, 3.3), and living in a house made of mud wall $(\mathrm{OR}=3.7$; 95\% CI: 1.5, 7.5) were independently associated with the development of active tuberculosis in people living with HIV/AIDS.

CONCLUSION: All people living with HIV/AIDS should be screened for tuberculosis but in the presence of the risk factors mentioned above, intensified screening is recommended.

KEYWORDS: Active TB, HIV, risk factors, case control study, Southwest Ethiopia

\section{INTRODUCTION}

Infection with Tuberculosis (TB) is the result of a complex interaction between the environment, the host and the pathogen $(1,2)$. TB control strategies mainly focus on decreasing the transmission of mycobacterium tuberculosis through early detection and effective treatment of TB patients $(1$, $3)$. There is evidence that it is impossible to eliminate TB (incidence less than 1 per million population) by 2050 using this strategy alone(4). A comprehensive strategy focusing on major risk factors of TB is essential to achieve the 'Stop TB' partnership targets $(1,5)$. Risk factors of TB can be categorized as distal or proximate(1). Distal risk factors such as socio-economic status contribute to the development of TB indirectly whereas proximate determinants include those that increase

\footnotetext{
${ }^{1}$ Department of Epidemiology, Jimma University, Jimma, Ethiopia,

${ }^{2}$ Department of Epidemiology and Social Sciences, Antwerp University, Antwerp, Belgium,

${ }^{3}$ Department of Physiology and Biometrics, Ghent University, Belgium

${ }^{4}$ Departments of Clinical Sciences, Institute of Tropical Medicine, Antwerp, Belgium,

*Corresponding author: email- amare_deribew@yahoo.com/amare.deribew@ju.edu.et
} 
exposure to the infectious agent such as crowding and that impair the host immune system(1). Assessment of proximate determinants of TB which are amenable for interventions such as the host and environmental factors help to target strategies(1). Several studies on risk factors of TB were done in the general population(6-9) but the proximate determinants of active TB among HIV patients are not well elucidated in countries with limited resources. In this study, the distal and proximate determinants of active TB among PLHA were assessed in south-west Ethiopia.

\section{MATERIALS AND METHODS}

From January to March, 2009, a case control study was conducted in Jimma and Mettu Karl hospitals where the two hospitals serve as referral and treatment centers for HIV and TB in south-west Ethiopia. During the study period, a total of 1546 adults (1030 in Jimma \& 516 in Mettu Karl) with HIV infection were registered for HIV related care, of which 324 ( 286 in Jimma \& 38 in Mettu Karl) developed active pulmonary $\mathrm{TB}$ and diagnosis of TB was made by physicians based on the national TB guideline(10). TB patients who were below 15 years were excluded. From the source population, a total of 162 PLHA with active pulmonary TB (cases) and 647 PLHA with no active TB (controls) were randomly selected to participate in the study. The sample size was calculated using Epi Info 6.04 software (Center for Disease Control and Prevention, Atlanta, 2005) using the following parameters: proportion of males among the controls of $22.3 \%$, odds ratio (OR) of 1.8(11), 5\% significance level, power of $80 \%$, a case to control ratio of $1: 4$, and a nonresponse rate of $10 \%$. The distribution of cases and controls in the study hospitals is illustrated in Table 1.

Table 1-Number of cases and controls selected in two hospitals in Southwest Ethiopia, 2009.

\begin{tabular}{lccrr}
\hline Hospital & $\begin{array}{l}\text { Total number PLHA } \\
\text { *with no active TB } \\
\text { (source for controls) }\end{array}$ & $\begin{array}{l}\text { Total number PLHA with } \\
\text { active TB (source for cases) }\end{array}$ & & \multicolumn{2}{c}{ Sample size } \\
\cline { 4 - 5 } & 478 & 38 & 20 & Coses \\
\hline Metu hospital & 744 & 286 & 142 & 567 \\
Jimma Hospital & 1222 & 324 & 162 & 647 \\
Total & & &
\end{tabular}

*PLHA-People living with HIV/AIDS

Data were collected by trained nurses using a pretested structured questionnaire. The questionnaire consisted of distal and proximate determinants of active TB (Figure 1). The distal determinants contained information concerning residence, ownership of a house, marital status, educational status, employment and monthly income. The proximate determinants were categorized into host and environmental factors. The host factors included sex, age, past history of TB, use of substances such as smoking, alcohol and Khat (stimulant plant from Chata Edulis), infection with helminthes, presence of asthma or diabetes mellitus, body mass index (BMI), anemia, CD4 lymphocyte count and WHO clinical staging. The environmental factors consisted of a contact history with a TB patient in the family, type of wall and floor of a house, presence of a separate kitchen, availability of a waste disposal system, and finally crowding in the house.

Individuals' duration of smoking of any type of tobacco was categorized as "never", "less than six months" and "more than six months". Duration of consumption of any type of alcohol and Khat chewing was similarly categorized as "never", "less than six months and "more than six months". 


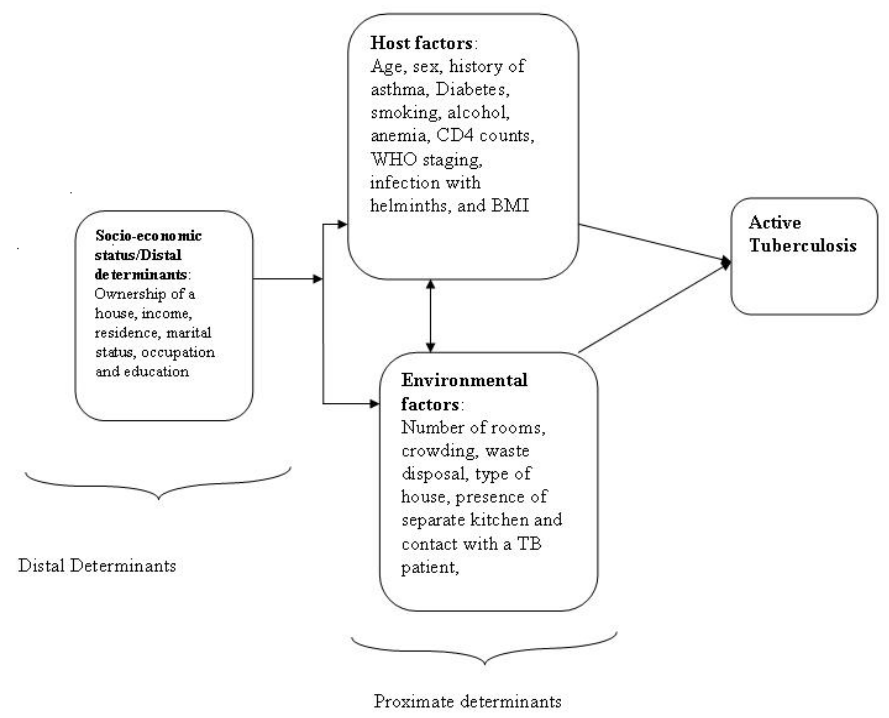

Figure 1-Determinants of active Tuberculosis in HIV patients

Stool samples were analyzed by formal-ether concentration method (12) and examined by laboratory technician using microscopy. Hemoglobin level was determined using the Hemo Cue analyzer (HemoCue $\mathrm{Hb}$ 301, Sweden) and anemia was defined as a hemoglobin level of less than $10.0 \mathrm{~g} / \mathrm{dl}$. Presence of malnutrition was determined by a BMI of less than $18.5 \mathrm{~kg} / \mathrm{m}^{2}$. Income was categorized into above and below the absolute poverty line of 330 Ethiopian Birr/month (about 30 USD). The adult crowding index was calculated by dividing the number of adults in a house by the number of rooms and three categories $(<1,1-2,>2)$ of crowding index were used. Data on CD4 lymphocyte count were extracted from the patients' record.

Data were cleaned for inconsistencies and missing values and analyzed using SPSS 16.0 statistical software. The Cochran-Mantel-Haenszel chi-square test was used to evaluate the association between distal, host and environmental risk factors with the occurrence of active TB. All variables with a significant association in the univariate analysis $(\mathrm{P}<0.05)$ were candidates to be included in the final multivariate logistic regression model. The final model was obtained by a forward and backward selection procedure.

Ethical clearance was obtained from the ethical committee of Jimma University and written consent was obtained from the study participants and confidentiality was assured for all the information provided.

\section{RESULTS}

Univariate analysis of factors associates with TB: In the univariate analysis, there were no significant differences between cases and controls concerning most of the distal determinants such as area of residence, ownership of a house, occupation and income. However, a higher proportion of single $(\mathrm{P}=0.004)$ and illiterate individuals $(\mathrm{P}<0.001)$ had active TB compared to married and literate individuals (Table-2). 
Table 2- Association of distal determinants and active tuberculosis in HIV patients, Southwest Ethiopia, 2009.

\begin{tabular}{lrllll}
\hline Variables & \multicolumn{2}{l}{ Cases } & \multicolumn{2}{l}{ Controls } & P-value \\
& $\mathrm{N}(\%)$ & $\mathrm{N}(\%)$ & \\
\hline Residence & 142 & $(87.7)$ & 590 & $(91.2)$ & 0.8 \\
$\quad$ Urban & 20 & $(12.3)$ & 57 & $(8.8)$ & \\
$\quad$ Rural & 64 & $(39.5)$ & 292 & $(45.1)$ & 0.2 \\
Ownership of a house & 98 & $(60.5)$ & 355 & $(54.9)$ & \\
$\quad$ Yes & & & & & \\
$\quad$ No & 69 & $(42.6)$ & 303 & $(46.8)$ & 0.004 \\
Marital status & 41 & $(25.3)$ & 94 & $(14.5)$ & \\
$\quad$ Married & 52 & $(32.1)$ & 250 & $(38.7)$ & \\
$\quad$ Single & & & & & \\
$\quad$ Divorced/ Widowed & 64 & $(39.5)$ & 126 & $(19.5)$ & $<0.001$ \\
Educational status & 30 & $(18.5)$ & 185 & $(28.6)$ & \\
$\quad$ No Formal education & 19 & $(11.7)$ & 98 & $(15.1)$ & \\
$\quad$ Elementary(grade 1-6) & 35 & $(21.6)$ & 187 & $(28.9)$ & \\
$\quad$ Junior secondary(grade $7-8)$ & 14 & $(8.5)$ & 51 & $(7.9)$ & \\
$\quad$ High school & & & & & \\
$\quad$ Above high school & 37 & $(22.8)$ & 176 & $(27.2)$ & 0.5 \\
Employment status & 125 & $(77.2)$ & 471 & $(72.8)$ & \\
$\quad$ Employed & & & & & \\
$\quad$ Unemployed & 80 & $(49.4)$ & 312 & $(48.2)$ & 0.8 \\
Monthly income in USD & 82 & $(50.6)$ & 335 & $(51.8)$ & \\
$\quad<30$ & & & & & \\
$\quad \geq 30$ & & & & &
\end{tabular}

Males were more likely to have active TB than females $(\mathrm{P}=0.007)$. A higher proportion of cases had a history of smoking of more than 6 months compared to controls $(\mathrm{P}<0.001)$. Infection with helminthes was more common among cases than controls $(\mathrm{P}<0.001)$. Individuals who had anemia (hemoglobin $<10.0 \mathrm{~g} / \mathrm{dl}$ ) were more likely to have active TB than individuals who had a higher hemoglobin level $(\mathrm{P}<0.001)$. A higher proportion of cases had a CD4 lymphocyte count less than 200 cells $/ \mu \mathrm{L}$ compared to controls $(\mathrm{P}<0.001)$. More cases $(69.1 \%)$ were in clinical stage IV of WHO compared to controls $(36.2 \%)$. A higher proportion of cases $(54.7 \%)$ had a BMI less than $18.5 \mathrm{~kg} / \mathrm{m}^{2}$ compared to controls $(27.2 \%)$ (Table$3)$.

A higher proportion of cases had a contact history with a TB patient in their family $(\mathrm{P}<0.001)$ as well a larger proportion of them were living in a house made of a mud wall compared to the control $(\mathrm{P}<0.001)$. In addition, controls were more likely to live in a house made of a cement floor
$(\mathrm{P}<0.001)$ and to have a separate kitchen $(\mathrm{P}<0.001)$ than cases. However, there was no significance difference between cases and controls concerning crowding index, availability of a waste disposal system and a latrine (Table-4).

Factors independently associated with active TB: After adjustment for potential confounders, male gender $(\mathrm{OR}=1.7 ; 95 \% \mathrm{CI}$ : $1.1,2.7)$, a low level of education $(\mathrm{OR}=2.8 ; 95 \% \mathrm{CI}: 1.1,7.1)$, a BMI less than $18.5 \mathrm{~kg} / \mathrm{m} 2(\mathrm{OR}=4.1 ; 95 \% \mathrm{CI}: 2.3$, 7.4), hemoglobin level less than $10.0 \mathrm{~g} / \mathrm{dl}$ $(\mathrm{OR}=2.8 ; 95 \% \mathrm{CI}: 1.5,5.2)$, a CD4 lymphocyte count less than 200 cells $/ \mu \mathrm{L}(\mathrm{OR}=9.8 ; 95 \% \mathrm{CI}$ : $5.5,17.5)$, a WHO clinical stage IV $(\mathrm{OR}=4.3 ; 95 \%$ CI: 2.6, 6.8), not taking ART $(\mathrm{OR}=3.1 ; 95 \% \mathrm{CI}$ : $1.9,4.9)$, an infection with helminthes $(\mathrm{OR}=2.2$; $95 \%$ CI: $1.4,3.4)$, a history of contact with a TB patient in the family $(\mathrm{OR}=2.0 ; 95 \% \mathrm{CI}: 1.2,3.3)$, and living in a house made of mud wall $(\mathrm{OR}=3.7$; $95 \%$ CI: $1.5,7.5)$ were independently associated with the occurrence of active TB (Table-5). 
Table 3- Association of host factors and active tuberculosis in HIV patients, Southwest Ethiopia, 20009.

\begin{tabular}{|c|c|c|c|c|c|}
\hline \multirow{2}{*}{$\begin{array}{l}\text { Variables } \\
\text { Sex }\end{array}$} & \multicolumn{2}{|c|}{ Cases, n (\%) } & \multicolumn{2}{|c|}{ Controls, n (\%) } & \multirow{2}{*}{ P-value } \\
\hline & & & & & \\
\hline Male & 79 & $(48.8)$ & 241 & $(37.2)$ & 0.007 \\
\hline Female & 83 & $(51.2)$ & 406 & $(62.8)$ & \\
\hline \multicolumn{6}{|l|}{ Age } \\
\hline $15-35$ years & 107 & $(66.0)$ & 379 & $(58.6)$ & 0.08 \\
\hline$\geq 35$ years & 55 & $(34.0)$ & 268 & (41.4) & \\
\hline \multicolumn{6}{|l|}{ Past history of TB } \\
\hline Yes & 70 & $(43.2)$ & 269 & $(41.6)$ & 0.7 \\
\hline No & 92 & $(56.8)$ & 378 & $(58.4)$ & \\
\hline \multicolumn{6}{|l|}{ Smoking } \\
\hline Never & 115 & $(71.0)$ & 541 & $(83.6)$ & $<0.001$ \\
\hline Less than 6 months & 1 & $(0.6)$ & 6 & $(0.9)$ & \\
\hline More than 6 months & 46 & $(28.4)$ & 100 & $(15.5)$ & \\
\hline \multicolumn{6}{|l|}{ Alcohol } \\
\hline Never & 100 & $(61.7)$ & 433 & $(66.9)$ & 0.3 \\
\hline Less than 6 months & 10 & $(6.2)$ & 24 & $(3.7)$ & \\
\hline More than 6 months & 52 & $(32.1)$ & 190 & (29.4) & \\
\hline \multicolumn{6}{|l|}{ Khat chewing } \\
\hline Never & 94 & $(58.0)$ & 420 & $(64.9)$ & 0.09 \\
\hline Less than 6 months & 11 & $(6.8)$ & 23 & (3.6) & \\
\hline More than 6 months & 57 & $(35.2)$ & 204 & $(31.5)$ & \\
\hline \multicolumn{6}{|l|}{ Helminthes infection } \\
\hline Yes & 65 & $(40.1)$ & 175 & $(27.0)$ & $<0.001$ \\
\hline No & 97 & $(59.9)$ & 472 & $(73.0)$ & \\
\hline \multicolumn{6}{|l|}{ Bronchial Asthma } \\
\hline Yes & 13 & $(8.0)$ & 32 & (4.9) & 0.13 \\
\hline No & 149 & $(92.0)$ & 615 & $(95.1)$ & \\
\hline \multicolumn{6}{|l|}{ History of Diabetes Mellitus } \\
\hline Yes & 2 & $(1.2)$ & 2 & $(0.3)$ & 0.13 \\
\hline No & 160 & $(98.8)$ & 645 & (99.7) & \\
\hline \multicolumn{6}{|l|}{ Haemoglobin(g/dl) } \\
\hline$<10$ & 41 & $(25.3)$ & 59 & $(9.1)$ & $<0.001$ \\
\hline $10-12.49$ & 58 & $(35.8)$ & 194 & $(30.0)$ & \\
\hline$\geq 12.5$ & 63 & $(38.9)$ & 394 & $(60.9)$ & \\
\hline Taking ART & & & & & $<0.001$ \\
\hline Yes & 83 & $(51.2)$ & 502 & (77.6) & \\
\hline No & 79 & $(48.8)$ & 145 & $(22.4)$ & \\
\hline CD4 lymphocyte count (cells/pL) & & & & & $<$ \\
\hline$<200$ & 82 & $(50.6)$ & 116 & $(17.9)$ & 0.001 \\
\hline $200-499$ & 53 & $(32.7)$ & 207 & $(32.0)$ & \\
\hline$\geq 500$ & 27 & $(16.7)$ & 324 & $(50.1)$ & \\
\hline \multicolumn{6}{|l|}{ WHO clinical staging } \\
\hline Stage III & 50 & $(30.9)$ & 413 & $(63.8)$ & $<0.001$ \\
\hline Stage IV & 112 & $(69.1)$ & 234 & $(36.2)$ & \\
\hline \multicolumn{6}{|l|}{ Isoniazide preventive therapy } \\
\hline Yes & 2 & $(1.2)$ & 27 & $(4.2)$ & 0.07 \\
\hline No & 160 & $(98.8)$ & 620 & $(95.8)$ & \\
\hline \multicolumn{6}{|l|}{ Body mass index (BMI) } \\
\hline$<18.5$ & 88 & $(54.3)$ & 176 & $(27.2)$ & $<0.001$ \\
\hline$\geq 18.5$ & 74 & $(45.7)$ & 471 & $(72.8)$ & \\
\hline
\end{tabular}


Table 4-Association of environmental factors and active tuberculosis in HIV patients, Southwest Ethiopia, 2009.

\begin{tabular}{|c|c|c|c|c|c|}
\hline \multirow{2}{*}{$\begin{array}{l}\text { Variables } \\
\begin{array}{l}\text { Presence of TB patient } \\
\text { the family }\end{array}\end{array}$} & \multicolumn{2}{|c|}{$\begin{array}{l}\text { Cases, } \\
\mathrm{N}(\%)\end{array}$} & \multicolumn{2}{|c|}{$\begin{array}{l}\text { Controls } \\
\mathrm{N}(\%)\end{array}$} & \multirow[t]{2}{*}{ P-value } \\
\hline & & & & & \\
\hline Yes & 52 & $(32.1)$ & 115 & $(17.8)$ & $<0.001$ \\
\hline No & 110 & $(67.9)$ & 532 & $(82.2)$ & \\
\hline \multicolumn{6}{|l|}{ Wall of house } \\
\hline Mud/mud brick & 52 & $(32.1)$ & 46 & (7.1) & $<0.001$ \\
\hline Cement & 110 & $(67.9)$ & 601 & (92.9) & \\
\hline \multicolumn{6}{|l|}{ Floor of house } \\
\hline Mud & 72 & $(44.4)$ & 151 & $(23.3)$ & $<0.001$ \\
\hline Cement & 90 & $(55.6)$ & 496 & $(76.7)$ & \\
\hline \multicolumn{6}{|c|}{$\begin{array}{l}\text { Availability of a separate } \\
\text { kitchen }\end{array}$} \\
\hline Yes & 117 & $(72.2)$ & 534 & $(82.5)$ & $<0.001$ \\
\hline No & 45 & $(27.8)$ & 113 & $(17.5)$ & \\
\hline \multicolumn{6}{|l|}{ Crowding index } \\
\hline$<1$ & 8 & $(4.9)$ & 32 & (4.9) & 0.2 \\
\hline $1-2$ & 109 & $(67.3)$ & 384 & $(59.4)$ & \\
\hline$>2$ & 45 & $(27.8)$ & 231 & $(35.7)$ & \\
\hline \multicolumn{6}{|c|}{ Availability of electricity } \\
\hline Yes & 147 & $(90.7)$ & 581 & $(88.9)$ & 0.7 \\
\hline No & 15 & $(9.3)$ & 66 & (10.1) & \\
\hline \multicolumn{6}{|l|}{ Availability of latrine } \\
\hline Yes & 143 & $(88.3)$ & 575 & (89.9) & 0.8 \\
\hline No & 19 & $(11.7)$ & 72 & (11.1) & \\
\hline \multicolumn{6}{|l|}{ Waste system } \\
\hline In the compound & 80 & $(49.4)$ & 330 & $(51.0)$ & 0.7 \\
\hline Outside the campus & 82 & $(50.6)$ & 317 & $(49.0)$ & \\
\hline \multicolumn{6}{|c|}{ Do animals in the house? } \\
\hline Yes & 48 & $(29.6)$ & 151 & $(23.3)$ & 0.09 \\
\hline No & 114 & $(70.4)$ & 496 & $(76.7)$ & \\
\hline
\end{tabular}

\section{DISCUSSION}

In this study, several host and environmental risk factors of active pulmonary TB were investigated in an HIV-infected population in south-west Ethiopia. Among the distal determinants, educational status was significantly associated with active TB which is consistent with other reports in Pakistan and India $(13,14)$. Several studies have shown that socio-economic status is a strong risk factor for occurrence of active TB (1517). In our study a "low monthly income" was not associated active TB but in Ethiopia estimations of income based on salaries do not reflect the actual income of individuals. However, poor housing conditions which is a proxy of low socio- economic status was associated with active TB. Previous reports also showed that a poor household and crowding were major risk factors for the development of TB (7-9). The association of male gender and active TB in this study is consistent with several previous reports $(6,7,9)$ and the effect could be a combination of behavioral, socioeconomic, and true biological/genetic factors $(2,7)$. The role of smoking in the development of active TB is well established $(18,19)$ but smoking was not associated with active TB in our study and this could be probably due to the low prevalence of smoking in our study population. There could also be a social desirability bias whereby smokers denied their smoking status. 
Table 5- Factors independently associated with active tuberculosis in HIV patients, Southwest Ethiopia, 2009.

\begin{tabular}{|c|c|c|}
\hline Variables & $\begin{array}{l}\text { Crude OR } \\
(95 \% \mathrm{CI})\end{array}$ & $\begin{array}{l}\text { Adjusted OR } \\
(95 \% \mathrm{CI})\end{array}$ \\
\hline \multicolumn{3}{|l|}{ Sex } \\
\hline Male & $1.6(1.1,2.3)$ & $1.7(1.1,2.7)$ \\
\hline Female & 1 & 1 \\
\hline \multicolumn{3}{|l|}{ Educational status } \\
\hline No Formal education & $1.9(1.0,3.6)$ & $2.8(1.1,7.1)$ \\
\hline Elementary(grade 1-6) & $0.6(0.3,1.2)$ & $1.2(0.5,3.1)$ \\
\hline Junior secondary(grade 7-8) & $0.7(0.3,1.5)$ & $1.6(0.6,4.6)$ \\
\hline High school & $0.6(0.3,1.3)$ & $1.1(0.4,2.7)$ \\
\hline Above high school & 1 & 1 \\
\hline \multicolumn{3}{|l|}{ BMI(weight/height²) } \\
\hline$<18.5$ & $3.23(2.26,4.6)$ & $4.1(2.3,7.4)$ \\
\hline$\geq 18.5$ & 1 & 1 \\
\hline \multicolumn{3}{|l|}{ Haemoglobin(g/dl) } \\
\hline$<10$ & $8.1(4.6,14.2)$ & $2.8(1.5,5.2)$ \\
\hline $10-12.49$ & $3.5(2.14,5.7)$ & $1.4(0.8,2.4)$ \\
\hline$\geq 12.5$ & 1 & 1 \\
\hline \multicolumn{3}{|l|}{ Taking ART } \\
\hline Yes & 1 & \\
\hline NO & $3.3(2.3,4.7)$ & $3.1(1.9,4.9)$ \\
\hline \multicolumn{3}{|l|}{ CD4 lymphocyte count(cells/ $\mu \mathrm{L})$} \\
\hline$<200$ & $8.5(5.2,13.7)$ & $9.8(5.5,17.5)$ \\
\hline $200-499$ & $3.0(1.8 .5 .0)$ & $3.0(1.7,5.5)$ \\
\hline$\geq 500$ & 1 & 1 \\
\hline \multicolumn{3}{|l|}{ WHO staging } \\
\hline Stage III & 1 & 1 \\
\hline Stage IV & $3.9(2.7,5.7)$ & $4.3(2.6,6.8)$ \\
\hline \multicolumn{3}{|l|}{ Helminths infection } \\
\hline Yes & $1.8(1.3,2.6)$ & $2.2(1.4,3.4)$ \\
\hline No & 1 & 1 \\
\hline \multicolumn{3}{|c|}{ Presence of TB patient in the family } \\
\hline Yes & $2.2(1.5,3.2)$ & $2.0(1.2,3.2)$ \\
\hline No & 1 & 1 \\
\hline \multicolumn{3}{|l|}{ Wall of house } \\
\hline Mud/mud brick & $6.2(3.96,9.65)$ & $3.7(1.5,7.5)$ \\
\hline Cement & 1 & 1 \\
\hline
\end{tabular}

A low CD4 lymphocyte count was strongly associated with the presence of active TB which is consistent with many other studies (20-22). The presence of $\mathrm{TB}$ can also decrease the CD4 lymphocyte count in patients with $\operatorname{HIV}(23,24)$.It has been documented that malnutrition is a major risk factor of TB (25) and in this study, a low BMI (a proxy measure of malnutrition) and a low hemoglobin level were strongly associated with active TB which is similar to other reports $(14,26-$ 28). There can be several explanations for the association between a low BMI and low hemoglobin with the development of TB. First, TB could lead to malnutrition and anemia through anorexia, an increased metabolic rate and malabsorption. On the other hand, malnutrition can aggravate the immune deficiency and increase the risk of active TB. 
An infection with helminthes was more common among TB patients compared to controls and a similar finding was observed in a study done in north Ethiopia (29). It is speculated that infection with helminthes can lead to the development of active TB through enhancing the helper T-cell type 2(Th-2) immune response(30).

A contact history with a TB patient was one of the most important predictors of active TB which is consistent with previous findings (6-8) where frequent contact with TB patients in a rural household can lead to increased transmission of TB. Moreover, clustering of TB in families can also be explained by a genetic factor which predispose individuals to infection with $\mathrm{TB}(30$, 31).

This study has the following limitations: First, a case control study can only identify associations. Second, recall bias might have affected the accuracy of information related to substance use such as cigarette smoking and alcohol consumption.

In conclusion, all PLHA should be screened for TB but in the presence of the risk factors mentioned in this paper, intensified screening is recommended.

\section{ACKNOWLEDGEMENTS}

The authors acknowledge Jimma University for funding the study and the study participants for their cooperation.

\section{REFERENCES}

1. Lonnroth K, Jaramillo E, Williams BG, Dye C, Raviglione M: Drivers of tuberculosis epidemics: the role of risk factors and social determinants. Soc Sci Med 2009;68(12):22402246.

2. Yim JJ, Selvaraj P: Genetic susceptibility in tuberculosis. Respirology, 2010; 15(2):241256.

3. WHO. The Stop TB Strategy-building on and enhancing DOTS to meet the Millenium Development Goals. WHO/HTM/TB2006. 368. Geneva, WHO, 2006.

4. Dye C, Williams BG: Eliminating human tuberculosis in the twenty-first century. $J R$ Soc Interface 2008;5(23):653-662.
5. Dye C, Maher D, Weil D, Espinal M, Raviglione M: Targets for global tuberculosis control. Int $J$ Tuberc Lung Dis 2006; 10(4):460-462.

6. Lienhardt C, Fielding K, Sillah J, Tunkara A, Donkor S, Manneh K, Warndorff D, McAdam KP, Bennett S: Risk factors for tuberculosis infection in sub-Saharan Africa: a contact study in The Gambia. Am J Respir Crit Care Med 2003;168(4):448-455.

7. Lienhardt C, Fielding K, Sillah JS, Bah B, Gustafson P, Warndorff D, Palayew M, Lisse I, Donkor S, Diallo S et al: Investigation of the risk factors for tuberculosis: a case-control study in three countries in West Africa. Int $J$ Epidemiol 2005;34(4):914-923.

8. Hill PC, Jackson-Sillah D, Donkor SA, Otu J, Adegbola RA, Lienhardt C: Risk factors for pulmonary tuberculosis: a clinic-based case control study in The Gambia. BMC Public Health 2006; 6:156.

9. Gustafson P, Gomes VF, Vieira CS, Rabna P, Seng R, Johansson P, Sandstrom A, Norberg $\mathrm{R}$, Lisse I, Samb B et al: Tuberculosis in Bissau: incidence and risk factors in an urban community in sub-Saharan Africa. Int $J$ Epidemiol 2004;33(1):163-172.

10. MOH: TB, leprosy and TB/HIV prevention and control program manual. Addis Ababa, Ethiopia. 2008.

11. Fugnudo Mbeki AG, Kuwala Lube: HIV/TB co infection. Sout Afr J trop dis 2006;13:234241.

12. Allen AV, Ridley DS: Further observations on the formol-ether concentration technique for faecal parasites. $J$ Clin Pathol 1970;23(6):545-546.

13. Hussain H, Akhtar S, Nanan D: Prevalence of and risk factors associated with Mycobacterium tuberculosis infection in prisoners, North West Frontier Province, Pakistan. Int J Epidemiol 2003;32(5):794-799.

14. Shetty N, Shemko M, Vaz M, D'Souza G: An epidemiological evaluation of risk factors for tuberculosis in South India: a matched case control study. Int J Tuberc Lung Dis 2006; 10(1):80-86.

15. Lopez De Fede A, Stewart JE, Harris MJ, Mayfield-Smith K: Tuberculosis in socioeconomically deprived neighborhoods: missed 
opportunities for prevention. Int $J$ Tuberc Lung Dis 2008;12(12):1425-1430.

16. Muniyandi $M, \quad$ Ramachandran $R$ : Socioeconomic inequalities of tuberculosis in India. Expert Opin Pharmacother 2008; 9(10):1623-1628.

17. Mackenbach JP, Stirbu I, Roskam AJ, Schaap MM, Menvielle G, Leinsalu M, Kunst AE: Socioeconomic inequalities in health in 22 European countries. $N$ Engl $J$ Med 2008;358(23):2468-2481.

18. Ariyothai N, Podhipak A, Akarasewi P, Tornee S, Smithtikarn S, Thongprathum P: Cigarette smoking and its relation to pulmonary tuberculosis in adults. Southeast Asian J Trop Med Public Health 2004;35(1):219-227.

19. Lin HH, Ezzati M, Chang HY, Murray M: Association between tobacco smoking and active tuberculosis in Taiwan: prospective cohort study. Am J Respir Crit Care Med 2009;180(5):475-480.

20. Colebunders R, John L, Huyst V, Kambugu A, Scano F, Lynen L: Tuberculosis immune reconstitution inflammatory syndrome in countries with limited resources. Int J Tuberc Lung Dis 2006;10(9):946-953.

21. Lawn SD, Myer L, Bekker LG, Wood R: Tuberculosis-associated immune reconstitution disease: incidence, risk factors and impact in an antiretroviral treatment service in South Africa. Aids 2007;21(3):335341.

22. Grant AD, Bansi L, Ainsworth J, Anderson J, Delpech V, Easterbrook P, Fisher M, Gazzard $\mathrm{B}$, Gilson R, Gompels $\mathrm{M}$ et al: Tuberculosis among people with HIV infection in the United Kingdom: opportunities for prevention? Aids 2009;23(18):2507-2515.

23. Canaday DH, Wu M, Lu S, Aung H, Peters P, Baseke J, Mackay W, Mayanja-Kizza H, Toossi Z: Induction of HIV type 1 expression correlates with $\mathrm{T}$ cell responsiveness to mycobacteria in patients coinfected with HIV type 1 and Mycobacterium tuberculosis. AIDS Res Hum Retroviruses 2009; 25(2):213-216.

24. Habib AG: A clinical and epidemiologic update on the interaction between tuberculosis and human immunodeficiency virus infection in adults. Ann Afr Med 2009;8(3):147-155.

25. Vijayakumar M, Bhaskaram P, Hemalatha P: Malnutrition and childhood tuberculosis. $J$ Trop Pediatr 1990;36(6):294-298.

26. Pakasi TA, Karyadi E, Dolmans WM, van der Meer JW, van der Velden K: Malnutrition and socio-demographic factors associated with pulmonary tuberculosis in Timor and Rote Islands, Indonesia. Int $J$ Tuberc Lung Dis 2009;13(6):755-759.

27. Paton NI, Castello-Branco LR, Jennings G, Ortigao-de-Sampaio MB, Elia M, Costa S, Griffin GE: Impact of tuberculosis on the body composition of HIV-infected men in Brazil. J Acquir Immune Defic Syndr Hum Retrovirol 1999;20(3):265-271.

28. Karyadi E, Schultink W, Nelwan RH, Gross R, Amin Z, Dolmans WM, van der Meer JW, Hautvast JG, West CE: Poor micronutrient status of active pulmonary tuberculosis patients in Indonesia. $J$ Nutr 2000;130(12):2953-2958.

29. Elias D, Mengistu G, Akuffo H, Britton S: Are intestinal helminths risk factors for developing active tuberculosis? Trop Med Int Health 2006;11(4):551-558.

30. Fine PE: Immunogenetics of susceptibility to leprosy, tuberculosis, and leishmaniasis. An epidemiological perspective. Int J Lepr Other Mycobact Dis 1981;49(4):437-454.

31. Singh M, Balamurugan A, Katoch K, Sharma SK, Mehra NK: Immunogenetics of mycobacterial infections in the North Indian population. Tissue Antigens 2007;69 Suppl $1: 228-230$. 